\title{
Aberrant DNA methylation of GATA binding protein 3 (GATA3), interleukin-4 (IL-4), and transforming growth factor- $\beta$ (TGF- $\beta$ ) promoters in Behcet's disease
}

\author{
Yunyun Zhu ${ }^{1}$, Yiguo Qiu ${ }^{1}$, Hongsong $\mathbf{Y u}^{1}$, Shenglan $\mathrm{Yi}^{1}$, Wencheng Su ${ }^{1}$, Aize Kijlstra ${ }^{2}$ \\ and Peizeng Yang ${ }^{1}$ \\ ${ }^{1}$ The First Affiliated Hospital of Chongqing Medical University, Chongqing Key Laboratory of Ophthalmology and Chongqing \\ Eye Institute, Chongqing, China \\ ${ }^{2}$ University Eye Clinic Maastricht, Maastricht, The Netherlands \\ Correspondence to: Peizeng Yang, email: peizengycmu@126.com \\ Keywords: DNA methylation, Behcet's disease, CD4 $4^{+}$cell \\ Received: May 19, $2017 \quad$ Accepted: June 12, $2017 \quad$ Published: July 22, 2017 \\ Copyright: Zhu et al. This is an open-access article distributed under the terms of the Creative Commons Attribution License 3.0 \\ (CC BY 3.0), which permits unrestricted use, distribution, and reproduction in any medium, provided the original author and source \\ are credited.
}

\section{ABSTRACT}

The pathogenesis of Behcet's disease (BD) remains poorly understood. The purpose of this study was to investigate whether an aberrant DNA methylation of transcriptional and inflammatory factors, including TBX21, GATA3, RORYt, FOXP3, $I F N-y, I L-4, I L-17 A$ and $T G F-\beta$, in CD4 ${ }^{+} T$ confers risk to BD. We found that the promoter methylation level of GATA3, IL-4 and TGF- $\beta$ was significantly up-regulated in active $B D$ patients and negatively correlated with the corresponding mRNA expression. The mRNA expression of GATA3 and TGF- $\beta$ was markedly down-regulated in active $B D$ patients compared to healthy individuals. Treatment with corticosteroids and cyclosporine (CsA) resulted in a decrease of the methylation level of GATA3 and TGF- $\beta$ in inactive BD patients. Our results suggest that an aberrant DNA methylation of GATA3 and TGF- $\beta$ is associated with their mRNA expression and participates in the pathogenesis of $B D$.

\section{INTRODUCTION}

Behcet's disease (BD) is an autoimmune-mediated multisystemic inflammatory disease featured by diverse clinical manifestations including recurrent uveitis, oral and genital ulceration, and multiform skin lesions. It is prevalent in the region of the ancient Silk Route, such as Japan, China and Turkey $[1,2]$. Although the pathogenesis of $\mathrm{BD}$ is still not clear, numerous studies have suggested that environmental factors, infection triggers, abnormal autoimmune regulation and genetic susceptibility are closely associated with BD [3]. Previous studies have demonstrated a crucial role for T lymphocytes in the pathogenesis of autoimmune diseases, including BD. Early studies reported that hyperactive T helper (Th) type 1 and Th17 immune responses were related to the development of $\mathrm{BD}[4,5]$.
T helper (Th) type 1, Th2, Th17 and regulatory T cell (Treg) are the major subpopulations of $\mathrm{CD} 4^{+} \mathrm{T}$ cells. TBX21 (Th1), GATA3 (Th2), ROR $\gamma t$ (Th17) and FOXP3 (Treg) are the primary subset-specific transcription factors of these $C D 4^{+} T$ cell subsets and can regulate $T$ cell differentiation. An earlier study found that the ratio of Th1/Th17 cells was decreased in BD patients with uveitis [5], and another study reported an increase in the ratios of RORC/FOXP3 and TBX21/GATA3 in neuroBehçet's disease, suggesting a dysregulation of Th1, Th2, Th17 and Tregs in this disease [6]. Interferon- $\gamma$, $I L-4, I L-17$ and $T G F-\beta$ are the central inflammatory cytokines of Th1, Th2, Th17 and Treg cells, respectively. The expression of lineage-specific transcription factors is also crucial in regulating the production of $\mathrm{T}$ helper profile-associated cytokines. A previous study from our team showed that the mRNA expression of $I L-17$ and 
Table 1: Primer sequence of target genes for amplifying bisulfite-treated DNA.

\begin{tabular}{|c|c|c|c|c|c|c|}
\hline Gene & Chr & Location & Primer sequence & $\begin{array}{l}\text { Target } \\
\text { Length }\end{array}$ & CpGs & $\mathbf{T m}$ \\
\hline$T B X 21$ & 17 & $-593 \sim-411$ & $\begin{array}{l}\text { forward:ggaagagagGTTTTTGAGTGTTAGGAGAATGTTTA } \\
\text { reverse:taatacgactcactatagggagaaggctAAAATCTTACTTTCTAAAAATATCAACTCC }\end{array}$ & 182 & 3 & 56 \\
\hline$R O R \gamma t$ & 1 & $\begin{array}{c}-1228 \sim- \\
1015\end{array}$ & $\begin{array}{c}\text { forward:ggaagagagGGGAGATTTTGGGAGTTATTTAAGA } \\
\text { reverse:aatacgactcactatagggagaaggctAAACAACAAAACAAAAATCAACCAT }\end{array}$ & 214 & 1 & 56 \\
\hline GATA3 & 10 & $\begin{array}{l}-2316 \sim- \\
2167\end{array}$ & $\begin{array}{c}\text { forward:aggaagagagTTTTTTTTGGTAGTATTGTTTTGGG } \\
\text { reverse:cagtaatacgactcactatagggagaaggctATCCTTTAAACCACTACATCCCCTA }\end{array}$ & 149 & 8 & 56 \\
\hline FOXP3 & $\mathrm{X}$ & $-307 \sim+86$ & $\begin{array}{c}\text { forward:aggaagagagGATATTTTTTATTTTTGTGGTGAGGG } \\
\text { reverse:cagtaatacgactcactatagggagaaggctCCTCCAATAAAACCCACATCTAATA }\end{array}$ & 393 & 3 & 56 \\
\hline$I F N-\gamma$ & 12 & $-348 \sim+101$ & $\begin{array}{l}\text { forward:aggaagagagAAGATTAGTTAAGTTTTTTGGATTTGATT } \\
\text { reverse:cagtaatacgactcactatagggagaaggctCTACCTACAAAAAATAACAACCTATCA }\end{array}$ & 297 & 1 & 56 \\
\hline$I L-4$ & 5 & $-182 \sim+182$ & $\begin{array}{l}\text { forward:aggaagagagGTGTTGATTGGTTTTAAGTGATTGA } \\
\text { reverse:cagtaatacgactcactatagggagaaggctAAACATCACCAAAACATCTAAAAAAA }\end{array}$ & 364 & 2 & 56 \\
\hline IL-17A & 6 & $-195 \sim+86$ & $\begin{array}{c}\text { forward:aggaagagagGAGATTTTTTTATGATTTTATTGGGG } \\
\text { reverse:cagtaatacgactcactatagggagaaggctTCCAAAAATACTATCTAATCCAAATCAAC }\end{array}$ & 281 & 1 & 56 \\
\hline$T G F-\beta$ & 19 & $-701 \sim-495$ & $\begin{array}{l}\text { forward:aggaagagagGTAGTTTGAGGTTTTAGAGTTTGAGA } \\
\text { reverse:cagtaatacgactcactatagggagaaggctAAAATCCCCAAATCCTACCTCC }\end{array}$ & 206 & 10 & 56 \\
\hline
\end{tabular}

$I F N-\gamma$ was significantly increased in active BD patients [4], and another study showed that cyclosporine A (CsA) can markedly inhibit the production of both $I L-17$ and $I F N-\gamma$ in BD patients [7]. Earlier studies also showed that the cytokine production of $I L-4$ was higher in peripheral blood mononuclear cells (PBMCs) and serum from patients with $\mathrm{BD}[8,9]$.

DNA methylation refers to enzymatic addition of a methyl group to the fifth carbon of cytosine at $\mathrm{CpG}$ motifs, which is one of the crucial epigenetic mechanisms that can regulate the gene expression without changing the DNA sequence [10-12]. DNA hypomethylation is closely related to transcriptional activation, while DNA hypermethylation is related to transcriptional silencing [13]. In recent years, a growing number of studies recognized the importance of DNA methylation in the immune response, especially in the cytokines produced during $\mathrm{T}$ cell differentiation [13-15]. Furthermore, various studies have shown that an abnormal DNA methylation may play an important role in the occurrence and development of many tumors [16-18]. In addition, accumulating evidence is available to show that aberrant DNA methylation of $\mathrm{CD}^{+} \mathrm{T}$ cells may play a key role in the pathogenesis of several immune mediated disorders [19-21]. Considering the crucial role of DNA methylation and $\mathrm{CD}^{+} \mathrm{T}$ cells in the pathogenesis of inflammatory disease, we decided to investigate whether DNA methylation of the major transcription factors and cytokines of $\mathrm{CD}^{+} \mathrm{T}$ cells had an impact on the development of BD. Our results suggest that hypermethylation of GATA3, IL-4 and TGF- $\beta$ confers risk to $\mathrm{BD}$.

\section{RESULTS}

\section{Increased methylation level of the $G A T A 3, I L-4$ and $T G F-\beta$ promoters was observed in $\mathrm{CD}^{+}{ }^{+} \mathrm{T}$ cells from active BD patients}

To investigate whether the methylation level of master transcription factors (TBX21, GATA3, ROR $\gamma$ and $F O X P 3)$ and inflammatory factors $(I F N-\gamma, I L-4$, $I L-17 A$ and $T G F-\beta)$ in $\mathrm{CD}^{+} \mathrm{T}$ cells is associated with $\mathrm{BD}$, we determined the promoter methylation level in active BD patients and healthy individuals. Because of the limitation of the MassARRAY system, we can only detect target sequences with a length between 100 to 500 base pairs. Detailed information of the target genes tested in this study is shown in Table 1. We were able to detect $8 \mathrm{CpG}$ sites in the GATA3 promoter whereby the methylation level of the CG-7.8.9 unit was found to be remarkably higher in active $\mathrm{BD}$ patients than that in normal subjects $(\mathrm{P}=0.001$, Table 2, Figure $1 \mathrm{~A})$. The methylation level of the other $\mathrm{CpG}$ sites was not significantly different between the two groups (Table 2). In the $I L-4$ promoter, we were able to detect $2 \mathrm{CpG}$ sites and found a hypermethylation of the $\mathrm{CG}-2$ site in active BD patients as compared to healthy subjects $(\mathrm{P}=0.012$, Table 2, Figure 1B). A total of $9 \mathrm{CpG}$ sites were detectable in the $T G F-\beta$ promoter and the methylation level of CG-2.3.4.5 and CG-10.11 units was significantly up-regulated in active $\mathrm{BD}$ patients when compared with controls $\left(\mathrm{P}=4.65 \times 10^{-4}, \mathrm{P}=2.85 \times 10^{-4}\right.$, respectively. Table 2 , Figure $1 \mathrm{C}$ and $1 \mathrm{D})$. The methylation levels of all $\mathrm{CpG}$ sites detected in this study are shown in Table 2. 
Table 2: Methylation levels of TBX21, GATA3, ROR $\gamma t, F O X P 3, I F N-\gamma, I L-4, I L-17 A$ and $T G F-\beta$ promoter in $\mathrm{CD}^{+}{ }^{+} \mathrm{T}$ cell from BD patients versus normal controls.

\begin{tabular}{|c|c|c|c|c|}
\hline Gene & CG sites & $\begin{array}{c}\text { BD methylation level } \\
(\%, \text { mean } \pm \text { SD })\end{array}$ & $\begin{array}{c}\text { CN methylation level } \\
(\%, \text { mean } \pm \text { SD })\end{array}$ & $p$ value \\
\hline \multirow{3}{*}{$T B X 21$} & CG2 & $63.8 \pm 3.6$ & $62.5 \pm 7.7$ & 0.53 \\
\hline & CG3 & $7.3 \pm 1.1$ & $7.9 \pm 1.7$ & 0.30 \\
\hline & CG4 & $8.8 \pm 1.6$ & $9.4 \pm 2.0$ & 0.61 \\
\hline \multirow{5}{*}{ GATA3 } & CG1 & $2.8 \pm 1.8$ & $3.1 \pm 2.1$ & 0.80 \\
\hline & CG3.4 & $6.5 \pm 1.6$ & $5.8 \pm 1.9$ & 0.43 \\
\hline & CG5 & $3.9 \pm 0.01$ & $3.2 \pm 0.02$ & 0.33 \\
\hline & CG6 & $4.7 \pm 3.3$ & $2.9 \pm 1.9$ & 0.13 \\
\hline & CG7.8.9 & $7.2 \pm 1.9$ & $5.3 \pm 1.2$ & $0.001 * *$ \\
\hline \multirow[t]{2}{*}{$R O R \gamma t$} & CG5 & $67.1 \pm 7.1$ & $69.5 \pm 6.7$ & 0.34 \\
\hline & $\mathrm{CG} 2$ & $36.7 \pm 14.3$ & $34.1 \pm 10.1$ & 0.30 \\
\hline \multirow[t]{2}{*}{ FOXP3 } & CG3 & $38.6 \pm 15.9$ & $35.8 \pm 6.3$ & 0.86 \\
\hline & CG6 & $70.5 \pm 11.7$ & $68.1 \pm 13.7$ & 0.23 \\
\hline$I F N-\gamma$ & CG3 & $68.1 \pm 11.6$ & $66.2 \pm 10.8$ & 0.64 \\
\hline \multirow{2}{*}{$I L-4$} & CG2 & $75.4 \pm 9.3$ & $65.9 \pm 10.9$ & $0.012 *$ \\
\hline & CG5 & $81.0 \pm 6.3$ & $78.3 \pm 6.5$ & 0.22 \\
\hline$I L-17 A$ & CG1 & $82.3 \pm 10.8$ & $82.2 \pm 4.7$ & 0.98 \\
\hline \multirow{4}{*}{$T G F-\beta$} & CG2.3.4.5 & $7.8 \pm 3.2$ & $4.5 \pm 1.5$ & $4.65 \times 10^{-4 * * * *}$ \\
\hline & CG6 & $4.5 \pm 5.2$ & $2.9 \pm 2.4$ & 0.70 \\
\hline & CG10.11 & $10.0 \pm 3.1$ & $6.5 \pm 1.7$ & $2.85 \times 10^{-4 * * * *}$ \\
\hline & CG13.14 & $2.3 \pm 2.2$ & $1.9 \pm 1.7$ & 0.65 \\
\hline
\end{tabular}

BD patients ( $\mathrm{n}=16, \mathrm{M}: \mathrm{F}=14: 2)$; Age (year: mean \pm SD): $34.63 \pm 6.98$.

Normal controls ( $\mathrm{n}=18, \mathrm{M}: \mathrm{F}=14: 4)$; Age (year: mean \pm SD): $37.61 \pm 13.63$.

$* \mathrm{P}<0.05, * * \mathrm{P}<0.01, * * * \mathrm{P}<0.001$.

\section{Decreased mRNA expression of $G A T A 3$ and $T G F-\beta$ was detected in $\mathrm{CD}^{+} \mathrm{T}$ cells from active BD patients}

To investigate whether the aberrant DNA methylation in GATA3, $I L-4$ and $T G F-\beta$ is associated with their mRNA expression, we measured the mRNA expression of GATA3, $I L-4$ and $T G F-\beta$ in $C D 4^{+} \mathrm{T}$ cells. We found that the mRNA expression of GATA3 and $T G F-\beta$ was significantly reduced in active $\mathrm{BD}$ patients compared to normal subjects $(\mathrm{P}=0.011, \mathrm{P}=0.016$; Figure $2 \mathrm{~A}$ and $2 \mathrm{~B})$. However, the mRNA expression of $I L-4$ was not significantly different between the two groups (data not shown). We subsequently analyzed the correlation between the DNA methylation and mRNA expression with the Pearson correlation test and found that the methylation level of the CG-7.8.9 units in GATA3, CG-2.3.4.5 and CG-10.11 units in TGF- $\beta$ were negatively correlated with their corresponding mRNA expression $\quad(\mathrm{P}=0.192, \quad \mathrm{r}=-0.45 ; \quad \mathrm{P}=0.017, \quad \mathrm{r}=-0.762$; $\mathrm{P}=0.169, \mathrm{r}=-0.502$; respectively. Figure $3 \mathrm{~A}-3 \mathrm{C}$ ).

\section{Down-regulated methylation level of GATA3 and $T G F-\beta$ promoters was detected in $\mathrm{CD}^{+} \mathrm{T}$ cells from inactive BD patients}

To investigate the association between GATA3 and $T G F-\beta$ promoter methylation with disease activity, we also measured the methylation level of GATA3 and $T G F-\beta$ in $\mathrm{CD}^{+} \mathrm{T}$ cells from inactive BD patients. The methylation status of CG-7.8.9 units in GATA3 was lower in inactive BD than that seen in active patients $\left(P=1.07 \times 10^{-6}\right.$, Figure 4A). Similarly, compared to active BD patients, the methylation level of CG-2.3.4.5 and CG-10.11 units in $T G F-\beta$ was also significantly reduced in $\mathrm{CD}^{+} \mathrm{T}$ cells from inactive $\mathrm{BD}$ patients $\left(\mathrm{P}=5.63 \times 10^{-5}\right.$, $\mathrm{P}=1.88 \times 10^{-4}$, Figure $4 \mathrm{~B}$ and $4 \mathrm{C}$ ). 

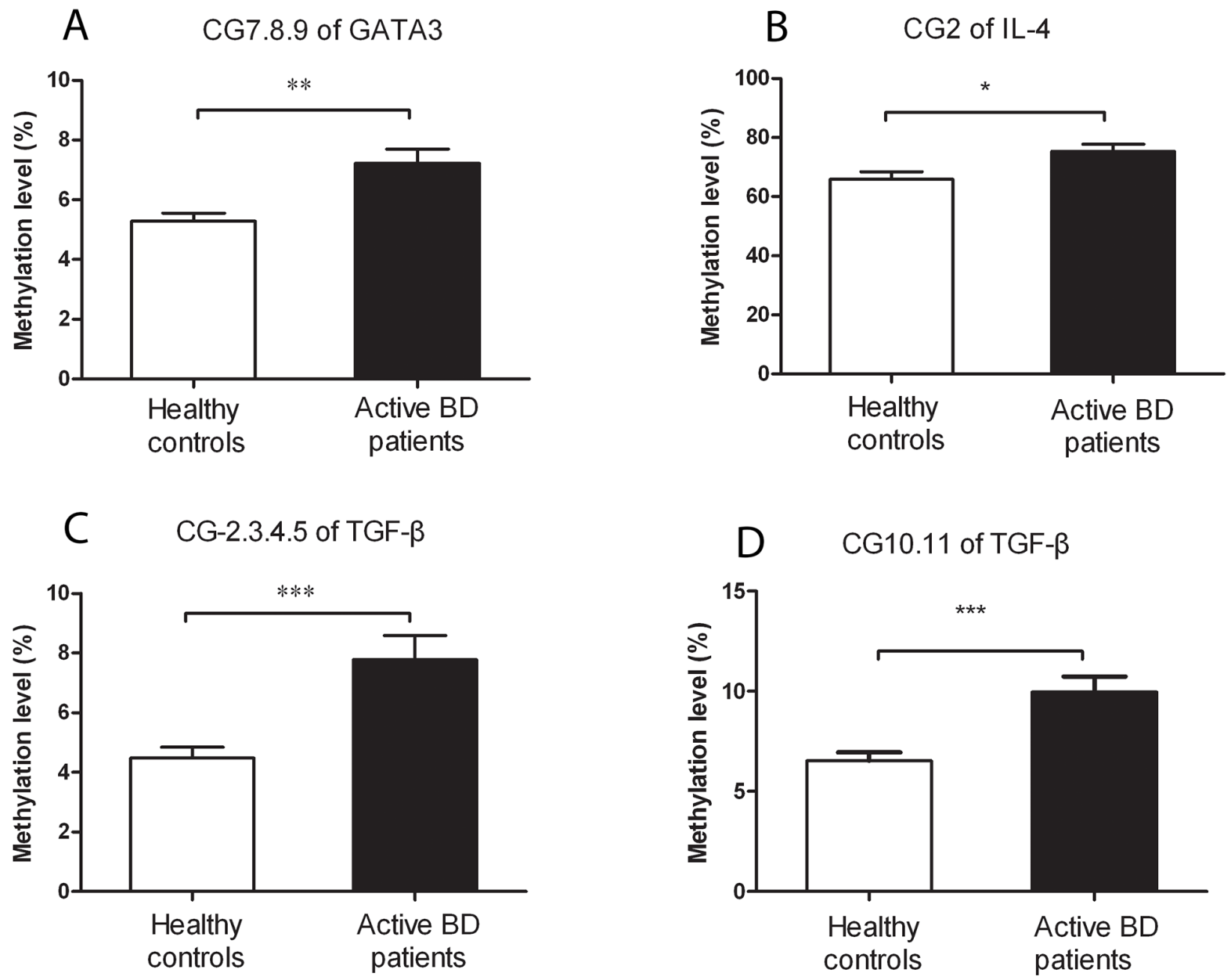

Figure 1: A higher methylation level of $G A T A 3, I L-4$ and $T G F-\beta$ is detected in $C D 4^{+}$T cells from active BD patients $(\mathbf{n = 1 6})$ when compared healthy controls $(\mathbf{n = 1 8})$. Methylation levels of the CpG-7. 8.9 unit in GATA3 (A), CpG-2 in IL-4 (B), as well as CpG-2.3.4.5 (C) and CpG-10.11 (D) in $T G F-\beta$ were all significantly up-regulated in BD patients compared to that in healthy controls. Data represent mean $\pm \mathrm{SEM}$. $* \mathrm{P}<0.05, * * \mathrm{P}<0.01$, *** $\mathrm{P}<0.001$.
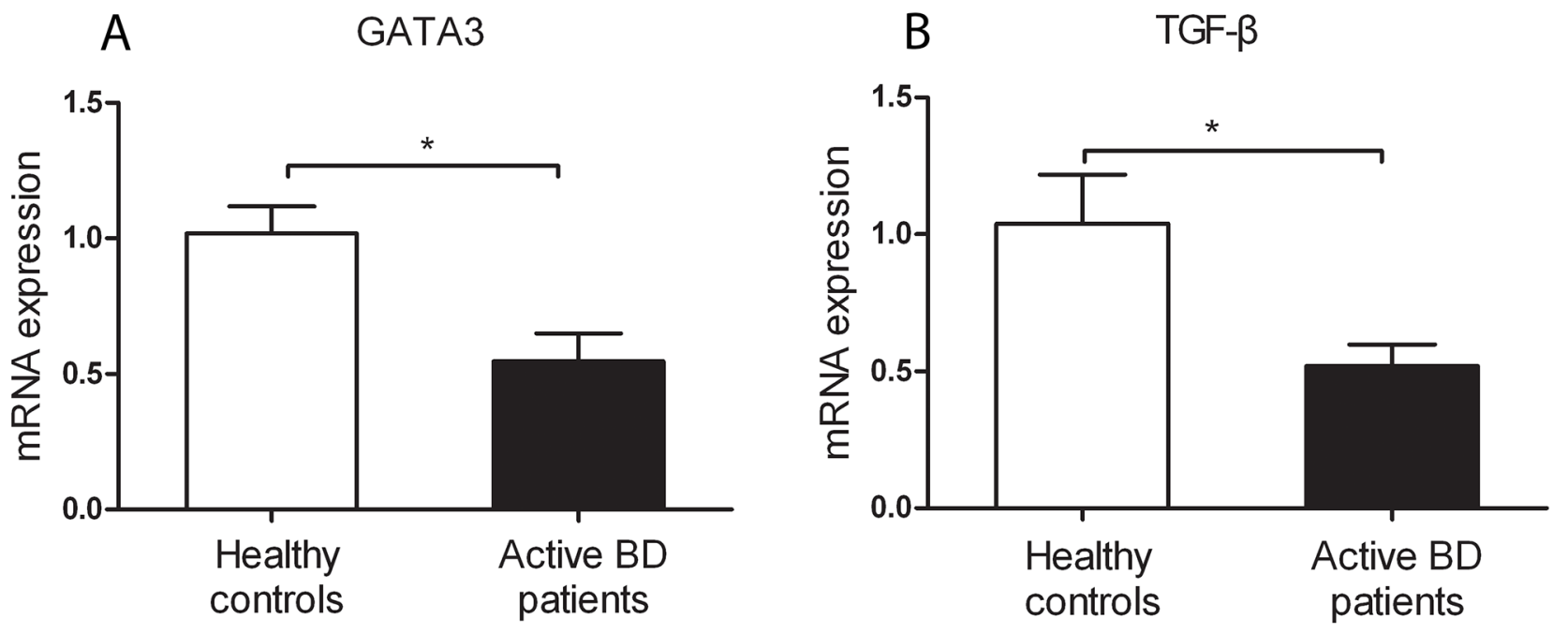

Figure 2: Decreased mRNA expression levels of GATA3 (A) and TGF- $\beta$ (B) were found in CD4 ${ }^{+}$T cell from active BD patients compared to healthy controls. BD patients: $n=5$; Normal controls $n=5$. Data represent mean $\pm S E M$. ${ }^{*} P<0.05$. 

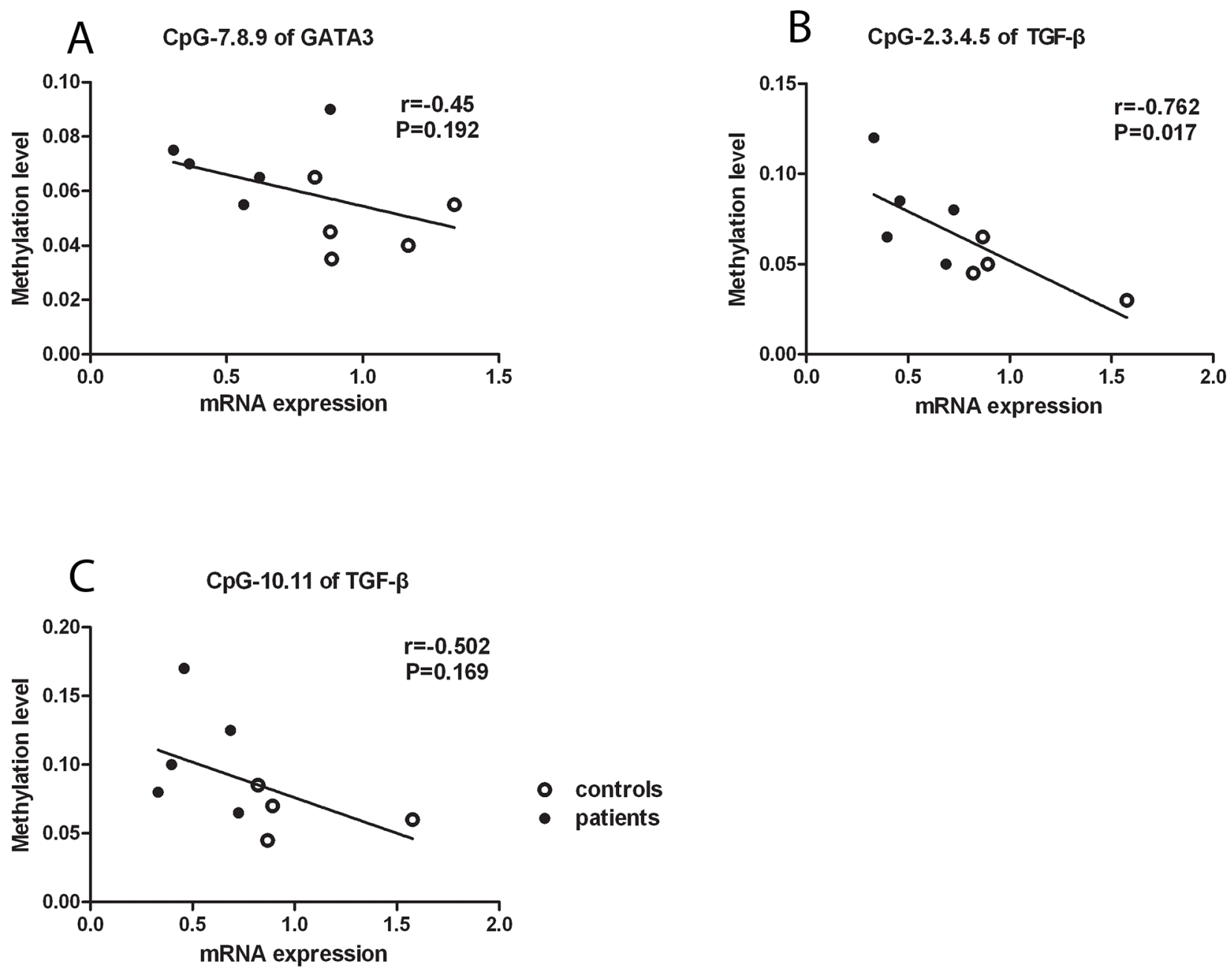

Figure 3: Negative correlation between DNA methylation and mRNA expression. The DNA methylation level of the CpG-7. 8.9 (A) unit in GATA3 as well as CpG-2.3.4.5 (B) and CpG-10.11 (C) units in $T G F-\beta$ were negatively related to their mRNA expression.

\section{DISCUSSION}

In the present study, we found that the methylation level of the CG-7.8.9 unit of GATA3, CG-2 site of $I L-4$ as well as CG-2.3.4.5 and CG-10.11 units of $T G F-\beta$ was significantly elevated in $\mathrm{CD} 4^{+} \mathrm{T}$ cells from active BD patients. We furthermore showed that the mRNA expression of GATA3 and TGF- $\beta$ was down-regulated in active BD patients. In addition, the methylation status of CG-7.8.9 unit of GATA3, CG-2.3.4.5 and CG-10.11 units of $T G F-\beta$ was markedly lower in inactive BD patients (after treatment with corticosteroids and CsA) than that observed in active BD patients.

The findings from our study are in agreement with earlier observations showing that genetic polymorphisms and copy number variants in many immune-related genes show an association with $\mathrm{BD}$, including the transcription factors and cytokines of $\mathrm{CD}^{+} \mathrm{T}$ cell subsets $[22,23]$. Since genetic predisposition cannot completely explain the development of $\mathrm{BD}$, we have now extended these findings and provide evidence for a possible role of epigenetic regulation of $\mathrm{T}$ cell transcription factors in the pathogenesis of this disease.

GATA binding protein 3 is a very important transcription factor in regulating the differentiation of $\mathrm{T}$ helper cells and the expression of Th2 cytokines [24] [25, 26]. Early study had indicated that ablation of GATA3 resulted in an increased DNA methylation of the $I L-4$ gene locus and decreased Th2 cytokines production [24]. Tobacco smoking has been shown to cause a hypomethylation of three $\mathrm{CpG}$ sites within GATA3 and has been suggested to be associated with lung cancer [27]. Another study confirmed that the GATA3 gene was more strongly methylated in clear cell renal carcinoma (ccRCC) and was partly due to a loss of the expression of this gene [28]. Methylation of the $I L-4$ gene was moderately to highly elevated in prostate cancer cells and increased DNA methylation of GATA3 was observed in androgen negative prostate as compared to androgen positive cells [29]. Hypermethylation is not restricted to 
cancer since recent studies demonstrated that the GATA3 gene was also hypermethylated in ulcerative colitis [30]. The $I L-4$ gene was shown to be hypomethylated in a mouse model of childhood allergic asthma [31]. In the study reported here, we found that the methylation level of GATA3 was markedly increased in active BD patients and was negatively associated with gene expression. These data support a role for an abnormal DNA methylation of GATA3 in the development of BD.

Transforming growth factor- $\beta$ is an important pleiotropic cytokine which participates in the regulation of mammalian development, homeostasis, and the differentiation of Th17 and Treg lymphocytes as well as the pathogenesis of various cancers [32-34]. The microenvironment of mature $\mathrm{T}$ lymphocytes determines the cell outcome [35]. TGF- $\beta$ can induce inflammation by promoting the development of Th17 and can inhibit the immune response by facilitating the development of Tregs, thereby suppressing T helper cells [36]. A previous study identified 378 candidate methylated genes in ovarian cancer and reported many of these genes to be relevant in the suppression of $T G F-\beta$ pathway activity [37]. Transforming growth factor-beta-inducible gene h3 (TGFBI) hypermethylation has been shown to be associated with paclitaxel-resistance in ovarian cancer and was correlated with the loss of TGFBI mRNA expression [38]. Recent studies have demonstrated that the promoter methylation level of $T G F-\beta 1$ was significantly increased in gastric cancer patients, and it was more closely associated with Helicobacter pylori (H.pylori) positive patients [39]. Consistent with these previous findings, we found that the methylation level of the $T G F-\beta$ promoter was significantly elevated in active $\mathrm{BD}$ patients and was negatively correlated with its mRNA expression.
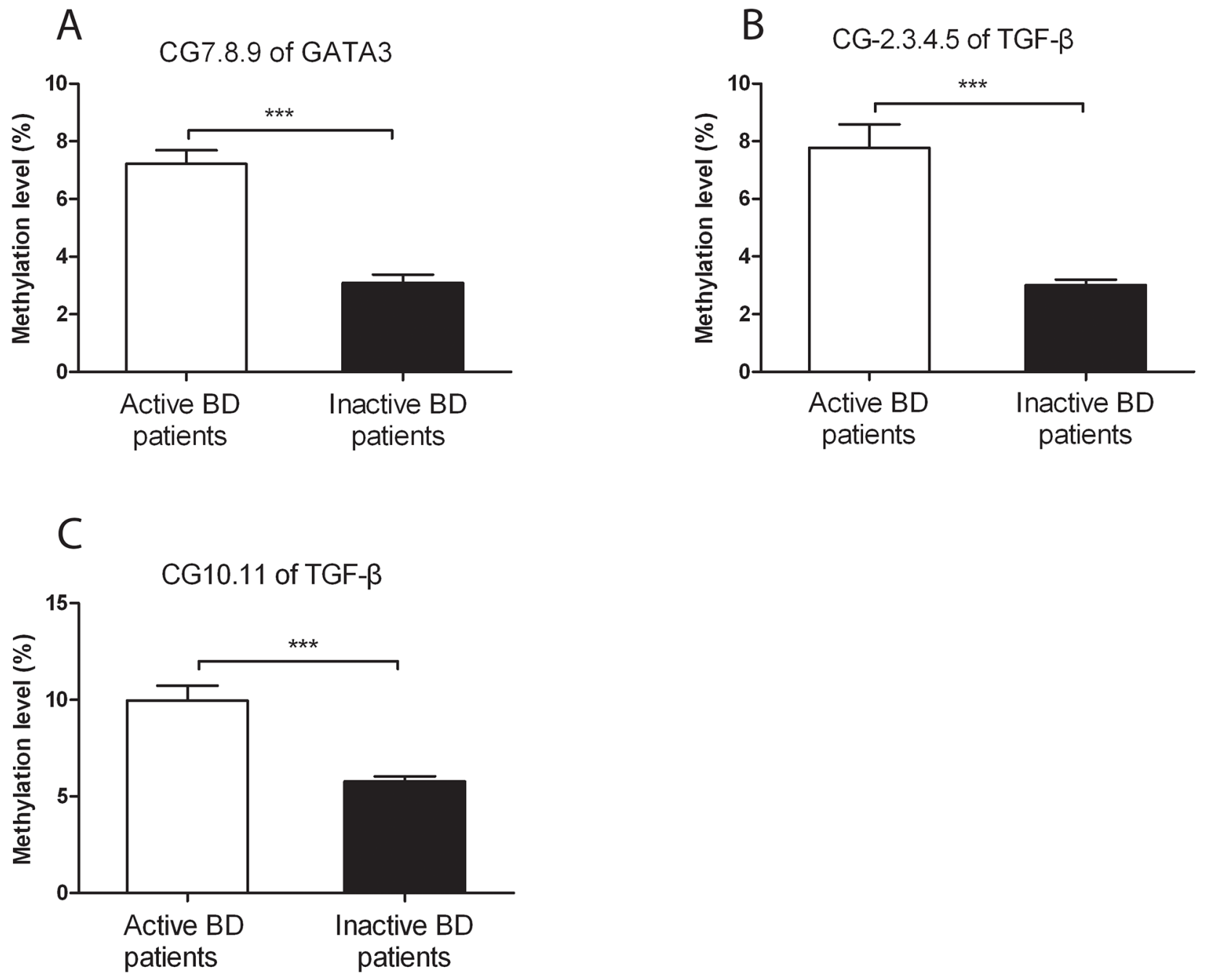

Figure 4: The DNA methylation levels of $G A T A 3$ and $T G F-\beta$ in $C D 4^{+} \mathrm{T}$ cells from active and inactive BD patients. Methylation levels of the CpG-7. 8.9 unit of GATA3 (A) as well as the CpG-2.3.4.5 (B) and CpG-10.11 (C) of TGF- $\beta$ were all significantly reduced in inactive $\mathrm{BD}$ as compared to that observed in active patients. Active BD: $\mathrm{n}=16$; inactive $\mathrm{BD}: \mathrm{n}=11$. Data represent mean $\pm \mathrm{SEM}$. $* * * \mathrm{P}<0.001$. 
In a recent study in another autoimmune uveitis entity named Vogt-Koyanagi-Harada (VKH) disease, we also found a hypermethylation of the GATA3, IL4 and $T G F-\beta$ promoters with a small difference [40]. It is well known that $\mathrm{BD}$ and $\mathrm{VKH}$ disease are quite different in clinical manifestations. Similar results about hypermethylation of these gene promoters may suggest that both diseases may have similar epigenetic regulation mechanisms. Further studies should be performed to explore whether the abnormal DNA methylation of GATA3, IL-4 and TGF- $\beta$ is also correlated with other uveitis entities. An epigeneticwide association study (EWAS) found 125 differentially methylated $\mathrm{CpG}$ sites in 62 genes that regulate cytoskeletal remodeling in $\mathrm{CD}^{+} \mathrm{T}$ cell from $\mathrm{BD}$ patients [41], but this study did not include GATA3, IL-4 and $T G F-\beta$ genes. The discrepancy may be caused by the fact that this latter EWAS study used the Illumina HumanMethylation450 DNA Analysis BeadChip array. To validate our results and analyze the relationship between methylation changes and clinical phenotypes of BD, further studies will be performed in a large casecontrol study.

In conclusion, the obtained results suggest that hypermethylation of GATA3 and TGF- $\beta$ may result in gene transcriptional silencing, which may play a role in the development of BD. Corticosteroids and CsA are the traditional drugs used for the treatment of uveitis, and a part of their beneficial effects may be caused by their ability to restore the aberrant methylation status of GATA3 and $T G F-\beta$. Further study is warranted to investigate whether the methylation status of GATA3 and TGF- $\beta$ promoters may represent potential biomarkers for disease diagnosis or treatment.

\section{MATERIALS AND METHODS}

\section{Study population}

A total of 16 active BD patients (mean age 34.63 \pm 6.98 years; 14 males, 2 females) without treatment, 11 inactive BD patients with treatment (mean age $39.55 \pm$ 7.54 years; 10 males, 1 females) and 18 sex- and agematched healthy subjects (mean age $37.61 \pm 13.63$ years; 14 males, 4 females) were recruited from the First Affiliated Hospital of Chongqing Medical University (Chongqing, China) from April 2015 to February 2017, to participate in this study. All participants were Chinese Han. The BD patients were diagnosed by the criteria of the International Study Group for Behcet's disease and all had uveitis [42]. Every patient and healthy individual provided informed consent for the current study. All procedures were in agreement with the tenets of the Declaration of Helsinki and approved by Ethics Research Committee of Chongqing Medical University.

\section{CD4 $^{+}$T-cell isolation}

Venous blood was drawn from participants using heparin-coated syringes. Peripheral blood mononuclear cells (PBMCs) were separated from blood samples by Ficoll-Hypaque density gradient centrifugation. $\mathrm{CD}^{+} \mathrm{T}$ cells were purified from PBMCs using CD4 mAbconjugated magnetic microbeads (Miltenyi Biotec, Bergisch Gladbach, Germany) in accordance with the manufacturer's protocol. The quality and purity of obtained $\mathrm{CD}^{+} \mathrm{T}$ cells were measured by flow cytometry and determined to be $>95 \%$.

\section{DNA extraction}

Genomic DNA was extracted from isolated $\mathrm{CD}^{+} \mathrm{T}$ cells using the QIAamp DNA Blood Mini Kit (Qiagen, Valencia, California, USA) according to the manufacturer's instruction. The DNA concentration and absorbance ratios of each sample were detected by a Nanodrop 2000 apparatus (Thermo Fisher Scientific, Wilmington, DE, USA).

\section{Sodium bisulfite modification}

Genomic DNA $(1 \mu \mathrm{g})$ of every sample was treated with the EZ DNA Methylation Kit (Agena Bioscience, California, USA) according to the instruction manual. The polymerase chain reaction (PCR) was performed during the bisulfate conversion, which included 20 cycles of the following two steps: $95^{\circ} \mathrm{C}$ for 30 seconds, $50^{\circ} \mathrm{C}$ for 15 minutes.

\section{Primer design for EpiTYPER assay}

DNA sequences and $\mathrm{CpG}$ units of gene promoters were determined by the UCSC website (http://www. genome.ucsc.edu). According to the identified DNA sequence, the upstream and downstream primers were designed by the EpiDesigner online application (http:// www.epidesigner.com). For each pair of primers, an additional $\mathrm{T} 7$ promoter tag and a 10-mer tag were added to the reverse and forward primer respectively. The $\mathrm{CpG}$ specific primer sequences and detailed information of the target genes are shown in Table 1.

\section{DNA methylation analysis by MassARRAY}

Quantitative methylation analysis was performed by the Sequenom's MassARRAY system (Sequenom Inc, San Diego, California, USA), which employs matrixassisted laser desorption/ionization-time of-flight mass spectrometer (MALDI-TOF-MS). Bisulfite-treated DNA was then subjected to the following reactions: PCR amplification $\left(94^{\circ} \mathrm{C}\right.$ for $4 \mathrm{~min}$; 45 cycles of $94^{\circ} \mathrm{C}$ for $20 \mathrm{~s}$, $56^{\circ} \mathrm{C}$ for $30 \mathrm{~s}$, and $72^{\circ} \mathrm{C}$ for $1 \mathrm{~min}$; then $72^{\circ} \mathrm{C}$ for $3 \mathrm{~min}$ ); dephosphorylated by shrimp alkaline phosphatase (SAP) 
(Sequenom) $\left(37^{\circ} \mathrm{C}\right.$ for $20 \mathrm{~min}, 85^{\circ} \mathrm{C}$ for $\left.5 \mathrm{~min}\right)$; followed by base specific cleavage $\left(37^{\circ} \mathrm{C}\right.$ for $\left.3 \mathrm{~h}\right)$. The resultant products were purified by the clean resin (Sequenom) and spotted on a 384-element silicon chip (SpectroCHIP, Sequenom, USA). Mass spectra were obtained using MassARRAY mass spectrometer and analyzed using EpiTYPER software v1.2 (Sequenom Inc, San Diego, California, USA) and the results were shown as percentages of methylation of each $\mathrm{CpG}$ site. The results were normalized by the methylation level of the test standard within the methylation analysis kit (Sequenom, Inc., San Diego, USA). Each sample was subjected to duplicate independent analyses and poor-quality and nonapplicable data were eliminated in the calculations.

\section{RNA extraction and real-time PCR}

Total RNA was extracted from $\mathrm{CD}^{+} \mathrm{T}$ cells by TRIzol reagent (Invitrogen, CA, USA) then used to synthesize complementary DNA by the PrimeScript RT kit (Takara, Dalian, China). Real-time PCR was performed by SYBR Premix (Takara Biotechnology, Dalian, China) with the ABI Prism 7500 system (Applied Biosystems, CA, USA). The mRNA expression was analyzed by the $2^{-\Delta \Delta \mathrm{Ct}}$ method. The primer sequences of $\beta$-actin and target genes for PCR were as follow: $\beta$-actin: forward: 5'-GGATGCAGAAGGAGATCACTG-3', reverse: 5'-CGATCCACACGGAGTACTTG-3'; GATA3: forward: 5'-GCGGGCTCTATCACAAAATGA-3', reverse: 5'-GCTCTCCTGGCTGCAGACAGC-3'; IL-4: forward: 5'-CACAACTGAGAAGGAAACCTTCTG-3', reverse: 5'-CTCTCTCATGATCGTCTTTAGCCTTTC-3'; $T G F-\beta$ : forward: 5'-GGACACCAACTATTGCTTCAG-3', reverse: 5'-TCCAGGCTCCAAATGTAGG-3'.

\section{Statistical analysis}

The statistical analyses were performed using SPSS 17.0 software (SPSS Inc, Chicago, Illinois, USA) and GraphPad Prism 5 software (GraphPad Software, Inc., CA). The Mann-Whitney test and independent-sample t-test were used to analyze the methylation level and mRNA expression, and the Pearson correlation test was used for the analysis of the correlation between DNA methylation and mRNA expression. A $p$-value less than 0.05 was regarded as significant difference.

\section{Abbreviations}

BD: Behcet's disease; ccRCC: clear cell renal carcinoma; CsA: Cyclosporin A; EWAS: epigenomewide association studies; FOXP3; forkhead box protein 3; GATA3: GATA binding protein 3; H.pylori: Helicobacter pylori; IFN- $\gamma$ : interferon- $\gamma$; IL: interleukin; MALDI-TOF-MS: matrix-assisted laser desorption/ ionization-time of-flight mass spectrometer; PBMCs: peripheral blood mononuclear cells; PCR: polymerase chain reaction; ROR $\gamma \mathrm{t}$ : retinoid-related orphan nuclear receptor $\gamma \mathrm{t}$; SAP: shrimp alkaline phosphatase; TBX21: T-box transcription factor 21 ; TGF- $\beta$ : transforming growth factor- $\beta$; TGFBI: transforming growth factor-betainducible gene h3; Th: T helper; Treg: regulatory T cell; VKH: Vogt-Koyanagi-Harada.

\section{Author contributions}

Y. Y. Z. and P. Z. Y. conceived the idea and designed the experiments. Y. Y. Z., Y. G. Q., W. C. S. and S. L. Y. contributed to sample collection. Y. Y. Z, Y.G. Q and H. S. Y. performed all the experiments. Y. Y. Z analyzed all data. Y. Y. Z wrote the first concept of the manuscript. P. Z. Y. and A. K. revised the manuscript critically for important intellectual content. All authors reviewed the manuscript.

\section{ACKNOWLEDGMENTS}

We would like to thank all participants enrolled for the present study.

\section{CONFLICTS OF INTEREST}

The authors proclaim no financial interests in the present study.

\section{FUNDING}

This work was supported by the Natural Science Foundation Major International (Regional) Joint Research Project (81320108009), Chongqing Key Laboratory of Ophthalmology (CSTC, 2008CA5003), National Key Clinical Specialties Construction Program of China, Chongqing Science \& Technology Platform and Base Construction Program (cstc2014pt-sy10002) and the Major Research Development Program of China (2016YFC0904000).

\section{REFERENCES}

1. Michelson JB, Friedlaender MH. Behcet's disease. Int Ophthalmol Clin. 1990; 30:271-278.

2. Bonfioli AA, Orefice F. Behcet's disease. Semin Ophthalmol. 2005; 20:199-206.

3. Yazici H. The lumps and bumps of Behcet's syndrome. Autoimmun Rev. 2004; 3:S53-S54.

4. Chi W, Zhu X, Yang P, Liu X, Lin X, Zhou H, Huang X, Kijlstra A. Upregulated IL-23 and IL-17 in Behcet patients with active uveitis. Invest Ophthalmol Vis Sci. 2008; 49:3058-3064.

5. Kim J, Park JA, Lee EY, Lee YJ, Song YW, Lee EB. Imbalance of Th17 to Th1 cells in Behcet's disease. Clin Exp Rheumatol. 2010; 28:S16-S19. 
6. Hamzaoui K, Borhani Haghighi A, Ghorbel IB, Houman H. RORC and Foxp3 axis in cerebrospinal fluid of patients with neuro-Behcet's disease. J Neuroimmunol. 2011; 233:249-253.

7. Chi W, Yang P, Zhu X, Wang Y, Chen L, Huang X, Liu X. Production of interleukin-17 in Behcet's disease is inhibited by cyclosporin A. Mol Vis. 2010; 16:880-886.

8. Raziuddin S, al-Dalaan A, Bahabri S, Siraj AK, al-Sedairy $\mathrm{S}$. Divergent cytokine production profile in Behcet's disease. Altered Th1/Th2 cell cytokine pattern. J Rheumatol. 1998; 25:329-333.

9. Mantas C, Direskeneli H, Eksioglu-Demiralp E, Akoglu T. Serum levels of Th2 cytokines IL-4 and IL-10 in Behcet's disease. J Rheumatol. 1999; 26:510-512.

10. Gibney ER, Nolan CM. Epigenetics and gene expression. Heredity (Edinb). 2010; 105:4-13.

11. Cedar H, Bergman Y. Linking DNA methylation and histone modification: patterns and paradigms. Nat Rev Genet. 2009; 10:295-304.

12. Egger G, Liang G, Aparicio A, Jones PA. Epigenetics in human disease and prospects for epigenetic therapy. Nature. 2004; 429:457-463.

13. Sawalha AH. Epigenetics and T-cell immunity. Autoimmunity. 2008; 41:245-252.

14. Strickland FM, Richardson BC. Epigenetics in human autoimmunity. Epigenetics in autoimmunity - DNA methylation in systemic lupus erythematosus and beyond. Autoimmunity. 2008; 41:278-286.

15. Santangelo S, Cousins DJ, Winkelmann NE, Staynov DZ. DNA methylation changes at human Th2 cytokine genes coincide with DNase I hypersensitive site formation during CD4(+) T cell differentiation. J Immunol. 2002; 169:1893-1903.

16. Tang Y, Jiang S, Gu Y, Li W, Mo Z, Huang Y, Li T, Hu Y. Promoter DNA methylation analysis reveals a combined diagnosis of CpG-based biomarker for prostate cancer. Oncotarget. 2017. Mar 22. https://doi.org/10.18632/ oncotarget.16437. [Epub ahead of print].

17. Morris MR, Latif F. The epigenetic landscape of renal cancer. Nat Rev Nephrol. 2017; 13:47-60.

18. Mishra NK, Guda C. Genome-wide DNA methylation analysis reveals molecular subtypes of pancreatic cancer. Oncotarget. 2017; 8:28990-29012. https://doi.org/ 10.18632/oncotarget.15993.

19. Zhang Y, Zhao M, Sawalha AH, Richardson B, Lu Q. Impaired DNA methylation and its mechanisms in CD4(+)T cells of systemic lupus erythematosus. J Autoimmun. 2013; 41:92-99.

20. Altorok N, Coit P, Hughes T, Koelsch KA, Stone DU, Rasmussen A, Radfar L, Scofield RH, Sivils KL, Farris AD, Sawalha AH. Genome-wide DNA methylation patterns in naive CD4+ T cells from patients with primary Sjogren's syndrome. Arthritis Rheumatol. 2014; 66:731-739.
21. Guo S, Zhu Q, Jiang T, Wang R, Shen Y, Zhu X, Wang Y, Bai F, Ding Q, Zhou X, Chen G, He DY. Genome-wide DNA methylation patterns in CD4+ T cells from Chinese Han patients with rheumatoid arthritis. Mod Rheumatol. 2017; 27:441-447.

22. Hou S, Liao D, Zhang J, Fang J, Chen L, Qi J, Zhang Q, Liu Y, Bai L, Zhou Y, Kijlstra A, Yang P. Genetic variations of IL17F and IL23A show associations with Behcet's disease and Vogt-Koyanagi-Harada syndrome. Ophthalmology. 2015; 122:518-523.

23. Hu J, Hou S, Zhu X, Fang J, Zhou Y, Liu Y, Bai L, Kijlstra A, Yang P. Interleukin-10 gene polymorphisms are associated with Behcet's disease but not with VogtKoyanagi-Harada syndrome in the Chinese Han population. Mol Vis. 2015; 21:589-603.

24. Yamashita M, Ukai-Tadenuma M, Miyamoto T, Sugaya K, Hosokawa H, Hasegawa A, Kimura M, Taniguchi M, DeGregori J, Nakayama T. Essential role of GATA3 for the maintenance of type 2 helper T (Th2) cytokine production and chromatin remodeling at the Th2 cytokine gene loci. J Biol Chem. 2004; 279:26983-26990.

25. Zheng W, Flavell RA. The transcription factor GATA-3 is necessary and sufficient for Th2 cytokine gene expression in CD4 T cells. Cell. 1997; 89:587-596.

26. Ouyang W, Ranganath SH, Weindel K, Bhattacharya D, Murphy TL, Sha WC, Murphy KM. Inhibition of Th1 development mediated by GATA-3 through an IL-4-independent mechanism. Immunity. 1998; 9:745-755.

27. Gao X, Zhang Y, Breitling LP, Brenner H. Tobacco smoking and methylation of genes related to lung cancer development. Oncotarget. 2016; 7:59017-59028. https://doi. org/10.18632/oncotarget.10007.

28. Cooper SJ, Zou H, Legrand SN, Marlow LA, von Roemeling CA, Radisky DC, Wu KJ, Hempel N, Margulis V, Tun HW, Blobe GC, Wood CG, Copland JA. Loss of type III transforming growth factor-beta receptor expression is due to methylation silencing of the transcription factor GATA3 in renal cell carcinoma. Oncogene. 2010; 29:2905-2915.

29. Mishra DK, Chen Z, Wu Y, Sarkissyan M, Koeffler HP, Vadgama JV. Global methylation pattern of genes in androgen-sensitive and androgen-independent prostate cancer cells. Mol Cancer Ther. 2010; 9:33-45.

30. Karatzas PS, Mantzaris GJ, Safioleas M, Gazouli M. DNA methylation profile of genes involved in inflammation and autoimmunity in inflammatory bowel disease. Medicine (Baltimore). 2014; 93:e309.

31. Collison A, Siegle JS, Hansbro NG, Kwok CT, Herbert C, Mattes J, Hitchins M, Foster PS, Kumar RK. Epigenetic changes associated with disease progression in a mouse model of childhood allergic asthma. Dis Model Mech. 2013; 6:993-1000.

32. Kawakami T, Soma Y, Kawa Y, Ito M, Yamasaki E, Watabe H, Hosaka E, Yajima K, Ohsumi K, Mizoguchi M. 
Transforming growth factor betal regulates melanocyte proliferation and differentiation in mouse neural crest cells via stem cell factor/KIT signaling. J Invest Dermatol. 2002; 118:471-478.

33. Huang JJ, Blobe GC. Dichotomous roles of TGF-beta in human cancer. Biochem Soc Trans. 2016; 44:1441-1454.

34. $\mathrm{Mu}$ Y, Gudey SK, Landstrom M. Non-Smad signaling pathways. Cell Tissue Res. 2012; 347:11-20.

35. Swist K, Pajtasz-Piasecka E. [The influence of transcription factors on CD4+ T cell differentiation]. [Article in Polish]. Postepy Hig Med Dosw (Online). 2011; 65:414-426.

36. Besnard AG, Sabat R, Dumoutier L, Renauld JC, Willart M, Lambrecht B, Teixeira MM, Charron S, Fick L, Erard F, Warszawska K, Wolk K, Quesniaux V, et al. Dual role of IL-22 in allergic airway inflammation and its crosstalk with IL-17A. Am J Respir Crit Care Med. 2011; 183:1153-1163.

37. Matsumura N, Huang Z, Mori S, Baba T, Fujii S, Konishi I, Iversen ES, Berchuck A, Murphy SK. Epigenetic suppression of the TGF-beta pathway revealed by transcriptome profiling in ovarian cancer. Genome Res. $2011 ; 21: 74-82$.
38. Wang N, Zhang H, Yao Q, Wang Y, Dai S, Yang X. TGFBI promoter hypermethylation correlating with paclitaxel chemoresistance in ovarian cancer. J Exp Clin Cancer Res. 2012; 31:6.

39. Wang YQ, Li YM, Li X, Liu T, Liu XK, Zhang JQ, Guo JW, Guo LY, Qiao L. Hypermethylation of TGF-beta1 gene promoter in gastric cancer. World J Gastroenterol. 2013; 19:5557-5564.

40. Zhu Y, Yu H, Qiu Y, Ye Z, Su W, Deng J, Cao Q, Yuan G, Kijlstra A, Yang P. Promoter hypermethylation of GATA3, IL-4, and TGF-beta confers susceptibility to Vogt-Koyanagi-Harada disease in Han Chinese. Invest Ophthalmol Vis Sci. 2017; 58:1529-1536.

41. Hughes T, Ture-Ozdemir F, Alibaz-Oner F, Coit P, Direskeneli H, Sawalha AH. Epigenome-wide scan identifies a treatment-responsive pattern of altered DNA methylation among cytoskeletal remodeling genes in monocytes and CD4+ T cells from patients with Behcet's disease. Arthritis Rheumatol. 2014; 66:1648-1658.

42. International Study Group for Behcet's Disease. Criteria for diagnosis of Behcet's disease. Lancet. 1990; 335:1078-1080. 